Marquette University

e-Publications@Marquette

College of Education Faculty Research and

Publications

Education, College of

$10-1-1996$

\title{
Childhood Memory and a History of Different Forms of Abuse
}

Timothy Melchert

Marquette University, timothy.melchert@marquette.edu

Accepted version. Professional Psychology: Research and Practice, Vol. 27, No. 5 (October1996):

438-446. DOI. (C) 2019 American Psychological Association. Used with permission.

Timothy P. Melchert was affiliated with Texas Tech University at the time of publication. 
Marquette University

e-Publications@Marquette

\section{Education Faculty Research and Publications/College of Education}

This paper is NOT THE PUBLISHED VERSION; but the author's final, peer-reviewed manuscript. The published version may be accessed by following the link in the citation below.

Professional Psychology : Research and Practice, Vol. 27, No. 5 (1996): 438-446. DOI. This article is (C) American Psychological Association and permission has been granted for this version to appear in $\underline{\mathrm{e}}-$ Publications@Marquette. American Psychological Association does not grant permission for this article to be further copied/distributed or hosted elsewhere without the express permission from American Psychological Association.

\section{Childhood Memory and a History of Different Forms of Abuse}

Timothy P. Melchert

Texas Tech University, Lubbock, TX

Marquette University, Milwaukee, WI

\section{Biographical Information for Authors}

TIMOTHY P. MELCHERT received his PhD from the University of Wisconsin-Madison in 1992. He is an assistant professor in the Department of Psychology at Texas Tech University. His research interests include the assessment and effects of family of origin history and child maltreatment as well as the training of professional psychology students.

\section{Abstract}

A widespread professional and public controversy has recently emerged regarding recovered memo-ries of child sexual abuse, but the prevalence and nature of these memories have received limited empirical examination. This study ( $N=553$ nonclinical participants) found that very similar pro-portions of those with histories of physical, emotional, or sexual abuse reported that they had periods without memory of their abuse ( $21 \%, 18 \%$, and $18 \%$, respectively). The responses of approximately one half of these participants suggested that they lacked conscious access to their abuse memories, whereas the responses from the others suggested that they had conscious access to their memories. A great deal of variance was found in the reported quality of general 
childhood memory and the offset of infantile amnesia, and the findings also suggest that it is normative to recover memories of child-hood. Each of these variables was also unrelated to the experience of child abuse.

\section{Introduction}

It is only in the last three decades that child abuse has become recognized as a major social problem in this country (in 1962, Kempe, Silverman, Steele, Droegemueller, \& Silver were the first to bring widespread professional attention to the problem of child physical abuse), and child sexual abuse (SA) has been recognized as a prevalent problem for only about the last half of that period. In this relatively short period of time, widespread concern about the prevalence and consequences of child abuse has developed. In recent years, however, a heated public and professional controversy has developed around repressed and recovered child abuse memories, particularly those involving SA (e.g., Ganaway, 1989; Gardner, 1992; Herman, 1992; Loftus, 1993; Ofshe \& Watters, 1993; Pezdek, 1994). The intensity of this controversy grew significantly after many states began allowing adults to recover monetary damages from their SA perpetrators for injuries suffered as a result of the abuse that was remembered for the first time in adulthood.

There has long been a great deal of disagreement surrounding the concept of repression in psychology. In fact, Freud often used repression, dissociation, and other terms synonymously, and the literature on the subject has remained confusing ever since (Erdelyi, 1990; Singer, 1990). For example, Holmes (1974, 1990) concluded that repression does not exist after reviewing the experimental research on repression in the commonly accepted sense of the unconscious blocking of memories to avoid psychological pain. Erdelyi (1990), on the other hand, argued that Freud and others never intended for repression to be thought of as only an unconscious process, but that a variety of defense mechanisms may be involved. Many writers, both popular and professional, have recently argued that unconscious repression of SA is common because of the secretive, emotionally traumatic nature of sexual abuse (Bass \& Davis, 1988; Blume, 1990; Frederickson, 1992; Herman, 1992). Amnesia for psychological trauma has long been reported in the literature (e.g., in patients with hysteria and multiple

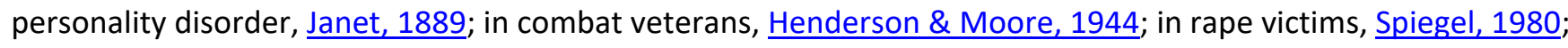
following the viewing of a shocking film, Loftus \& Burns, 1982), and there does appear to be consensus regarding the existence of the phenomenon (e.g., recent editions of the American Psychiatric Association's Diagnostic and Statistical Manual of Mental Disorders, 1980, 1987, 1994, have included syndromes involving amnesia for traumatic experiences). There is currently little agreement, however, regarding the prevalence or nature of amnesia for traumatic childhood experiences or the veridicality of all of the child abuse memories that are experienced as having been recovered after some period of amnesia for the events (e.g., American Medical Association Council on Scientific Affairs, 1994; American Psychological Association, 1994; Bass \& Davis, 1988; Ganaway, 1991; Herman, 1992; Lanning, 1992; Lindsay \& Read, 1994; Loftus, 1993; Pendergrast, 1995; Pope \& Hudson, 1995; Terr, 1991).

Human memory is clearly unreliable. A large amount of research as well as everyday experience suggest that memory is often distorted and inaccurate (for reviews, see Lindsay \& Read, 1994; Schacter, 1995), and children in particular have been shown to be influenced by suggestive questioning and other variables that can produce inaccurate memories (Ceci \& Bruck, 1995). Part of the controversy regarding repressed memories has concerned the remarkably early age at which some individuals have reported remembering SA victimization, but others contend such memories are not possible because of the age in the offset of infantile amnesia (e.g., Lindsay \& Read, 1994; Pope \& Hudson, 1995). On the other hand, some have argued that early traumatic abuse experiences can cause poor memory and even amnesia for one's childhood, and that poor childhood memory is a sign that abuse may have occurred (Blume, 1990; Courtois, 1988; Ellenson, 1985; Maltz, 1990). It appears that memory researchers are in agreement that it is possible to remember previously forgotten events from one's childhood, including abuse experiences, particularly when given appropriate cues (Lindsay \& Read, 1994; Loftus, Garry, \& Feldman, 1994); however, there is little agreement regarding the frequency, nature, or veridicality of recovered childhood abuse memories in general. Proposed mechanisms for the lack of continuous recall of abuse include simple forgetting and later remembering (Loftus, Garry, \& Feldman, 1994), dissociative amnesia 
(van der Kolk \& Kadish, 1987), "total" (Briere, 1992) or "robust" (Ofshe \& Singer, 1993) repression, implicit memory without explicit memory (Tobias, Kihlstrom, \& Schacter, 1992), and suggestibility (Ganaway, 1991; Loftus, 1993).

It is unfortunate that there has been little empirical investigation into the prevalence, nature, or veridicality of recovered child abuse memories. Only four studies have investigated these questions, and all have examined SA memories and not memories of physical or emotional abuse experiences. In the first of these studies, Herman and Schatzow (1987) found that $64 \%$ of 53 women in incest survivors therapy groups reported that they did not have full recall of the abuse, and $28 \%$ reported severe memory deficits. Young age at abuse and greater violence were associated with reports of greater forgetting of the abuse. Briere and Conte (1993) found that $59 \%$ of 420 women and 30 men who were in individual or group therapy for SA reported that there had been some period before they were 18 years old when they could not remember their SA. Briere and Conte also found that greater lack of recall was associated with earlier age at abuse, longer period of abuse, victimization by more perpetrators, and greater fear of death if the abuse were ever disclosed. Williams (1994) followed up on 129 women who had experienced documented SA 17 years earlier and found that $12 \%$ denied experiencing any SA during the follow-up interviews, and $38 \%$ did not report the documented instance, though two thirds of those who did not report the documented abuse did report other SA experiences. Use of physical force, genital trauma, and penetration were not associated with recall in this study. Loftus, Polonsky, and Fullilove (1994) found that $31 \%$ of the women in an outpatient substance abuse treatment program who reported SA claimed that they had incomplete memories for the abuse, and 19\% reported that they had forgotten the abuse for a period of time and the memories had later returned to them. Lack of recall for the abuse was unrelated to the level of violence of the abuse.

These studies provide widely differing estimates of the prevalence of lack of memory for SA (range $=19 \%$ to $59 \%)$. The highest rates of recovered memories were reported by Herman and Schatzow (1987) and by Briere and Conte (1993), who studied samples of psychotherapy clients. It is likely that higher rates of recovered memories would be reported in the clinical population, because a history of SA has been associated with mental health problems (Briere, 1988; Browne \& Finkelhor, 1986); however, a much lower rate of recovered memories was found by Loftus, Polonsky, and Fullilove (1994), who used a clinical sample of clients in substance abuse treatment. The samples in the Herman and Schatzow and the Briere and Conte studies were also susceptible to demand characteristics, however, because the participants in the first study were in therapy with the study's authors, and the participants in the second study were recruited by therapists associated with a particular referral organization.

The greatest difficulty, however, in assessing the prevalence of recovered SA memories using data from these studies results from insufficient information about the nature of the lack of continuous recall reported by the participants. For example, in the Briere and Conte (1993) study, participants were asked, "Was there ever a time when you could not remember the forced sexual experience?" (p. 24). In the Loftus, Polonsky, and Fullilove (1994) study, participants were asked if they were characteristic of people who "forget the abuse for a period of time, and only later have the memory return" (p. 75). It is possible that some participants answered affirmatively to these questions even though they did not lack conscious access to their SA memories, perhaps because they successfully avoided thinking about the unpleasant memories for a period of time though they could have remembered them if they had wanted to or were reminded, or perhaps because they were leading active, productive lives and were not predisposed to think about the unpleasant SA experiences. Some of the participants who were chemically dependent may not have been able to remember the abuse as the result of their substance use, which may even have been an intentional attempt to avoid the memories. It is sometimes assumed that individuals' affirmative responses to inquiries about the lack of continuous memory of abuse imply repression of the experiences, but the nature of the lack of memory recall that has been reported by many SA survivors has not been investigated and, consequently, remains unclear. 
This study investigated some of the unaddressed questions about child abuse and memory by examining the nature of memory for childhood generally, the relationship between child abuse experiences and the quality of general childhood memory, and the nature of recovered abuse memories, including memories for other types of child abuse besides SA. This study also included an investigation of gender effects-it has often been assumed that having false recovered abuse memories primarily affects women (e.g., Ganaway, 1995; Wakefield \& Underwager, 1992), but nearly all of the participants in the previous studies that examined this question have been women, and gender effects have not been examined to date. In addition, I used a nonclinical sample in this study so that possible demand characteristics resulting from being a client in mental health treatment could be minimized.

\section{Method}

\section{Participants}

The participant sample included 553 adults who attended a large research university in the southwestern United States. The sample was randomly selected through use of a psychology department participant pool. The mean age of the participants was young (19.7 years, $S D=3.1$, range $=17-46)$, and $60 \%$ were women. The majority of the total participant sample described their ethnic heritage as European American (82\%), $10 \%$ indicated Latin American, $5 \%$ indicated African American, and $4 \%$ indicated other ethnic heritages.

\section{Instrument}

The participants were administered the Family Background Questionnaire (Melchert \& Sayger, in press), an instrument designed to collect information regarding several areas of family-of-origin history before the age of 18. Seven of the items from that instrument inquire about SA and were used in this study. An additional 26 items inquire about several aspects of childhood memory, including memory for child abuse. The items that were used in this study are found in this article's tables, the appendix, and the section titled Results .

\section{Procedure}

The study questionnaire was administered in large lecture halls to groups of 68 to 98 participants. No two participants were allowed to sit next to each other; thus, they had some privacy when completing the questionnaire. Participation in the study was both anonymous and confidential. Signed informed consent forms were required of each respondent but were collected separately from the questionnaires to protect anonymity and confidentiality.

\section{Results}

\section{Childhood Physical, Emotional, and Sexual Abuse}

Just over one quarter ( $n=149,27 \%$ ) of the participants indicated that they had experienced one or more forms of child abuse (see Table 1). There was no significant difference between the proportions of male and female participants who reported physical abuse (PA) or emotional abuse (EA), but a significantly larger proportion of women than men reported some form of SA (see Table 2). (Given the number of comparisons made in this study, the level of alpha to indicate significance was reduced to .01.) The total number of reported SA incidents across perpetrator categories ranged from 0 to $85(M=6.2, S D=14.2)$. The range in age when the abuse occurred was reported as 3 to 18 years. The SA reported by this study sample is less than the prevalence of SA reported in general population studies (Finkelhor, Hotaling, Lewis, \& Smith, 1990, found rates of $27 \%$ for women and $16 \%$ for men in the only national survey conducted to date), but it is quite similar to the rates found in other studies of college students (for a review, see Starr, Dubowitz, \& Bush, 1990).

Table I. Number and Percentage Reporting Physical Abuse (PA), Emotional Abuse (EA), and Sexual Abuse (SA) 


\begin{tabular}{|l|l|l|l|l|l|l|}
\hline & Men & & Women & & Total \\
\hline Type of abuse & $\boldsymbol{n}$ & $\mathbf{\%}$ & $\boldsymbol{n}$ & $\%$ & $\boldsymbol{n}$ & $\%$ \\
\hline PA & 37 & 17 & 55 & 17 & 92 & 17 \\
\hline EA & 37 & 17 & 56 & 17 & 93 & 17 \\
\hline SA & 18 & 8 & 56 & 17 & $74^{\mathrm{a}}$ & 13 \\
\hline PA only & 10 & 5 & 10 & 3 & 20 & 4 \\
\hline EA only & 8 & 4 & 12 & 4 & 20 & 4 \\
\hline SA only & 4 & 2 & 25 & 8 & 29 & 5 \\
\hline PA and EA & 15 & 7 & 20 & 6 & 35 & 6 \\
\hline EA and SA & 2 & 1 & 6 & 2 & 8 & 1 \\
\hline PA and SA & 0 & 0 & 7 & 2 & 7 & 1 \\
\hline PA and EA and SA & 12 & 5 & 18 & 6 & 30 & 5 \\
\hline
\end{tabular}

${ }^{a}$ Gender difference significant, $p<.0 \mathrm{I}$.

Table 2. Number and Percentage Reporting Sexual Abuse by Gender and Perpetrator

\begin{tabular}{|l|l|l|}
\hline Alleged perpetrator & Male & Female \\
\hline Father & 0 & $10^{\mathrm{a}}$ \\
\hline$n$ & 0 & 3 \\
\hline$\%$ & & \\
\hline Mother & 0 & 2 \\
\hline$n$ & 0 & 1 \\
\hline$\%$ & & \\
\hline Other older relative & 5 & $31^{\mathrm{a}}$ \\
\hline$n$ & 2 & 10 \\
\hline$\%$ & & \\
\hline Other older people (e.g., baby-sitters, neighbors) & 11 & 21 \\
\hline$n$ & 5 & 6 \\
\hline$\%$ & & \\
\hline Other people (e.g., acquaintances, strangers) using physical force & 2 & $35^{\mathrm{a}}$ \\
\hline$n$ & 1 & 11 \\
\hline$\%$ & & \\
\hline Age the sexual contact first occurred & 8.4 & 7.7 \\
\hline$M$ & 1.7 & 3.6 \\
\hline SD & $7-11$ & $3-17$ \\
\hline Range & & \\
\hline Age the sexual contact last occurred & 8.8 & 11.3 \\
\hline$M$ & 2.1 & 4.5 \\
\hline SD & $7-11$ & $3-18$ \\
\hline Range & & \\
\hline Gender & & \\
\hline
\end{tabular}

${ }^{a}$ Gender difference significant, $p<.001$.

To examine the relationship between childhood abuse and memory, I computed an abuse severity measure that combined ratings of the severity of the three forms of abuse. Participants who indicated a history of PA, EA, or both were asked to rate the severity of their abuse on a 5-point scale ranging from 1 (mild) to 5 (severe), and the number of reported SA incidents was used to estimate the severity of SA. In addition to reporting more SA, women also had significantly higher PA ratings $(M=2.2, S D=1.2)$ than men $(M=1.5, S D=1.0), F(1,85)=9.35, p$ $=.009$, and women also had significantly higher EA ratings $(M=2.9, S D=1.1)$ than $\operatorname{men}(M=2.0, S D=1.0), F(1$, $\underline{85)}=11.80, p<.001$. 


\section{General Childhood Memory}

The participants were asked about the quality of their general childhood memory in addition to their age in their earliest memories (see Appendix). There was a large amount of variance in participants' responses to these items, but there was also substantial improvement in reported quality of memory over the period from age 2 years to age 10 years. As a group, the participants indicated that they were quite young in their earliest memories $(M=3.7$ years, $S D=2.1)$, but small numbers of participants also reported amnesia for their childhoods: $3 \%$ reported that their earliest memories were from age 10 or older. The five general childhood memory items were used as dependent variables and gender as the independent variable in a one-way multivariate analysis of variance (MANOVA) to test if there was a significant difference between women and men in general childhood memory. Using Wilks's criterion, I found no significant gender difference in the quality of childhood memory, $F(5,502)=.60, p=.70$.

To determine if those who reported experiencing various forms of child abuse had poorer childhood memory than those who had not, I used the five general childhood memory items as dependent variables and a history of $\mathrm{PA}, \mathrm{EA}$, and SA as independent variables in a $2 \times 2 \times 2$ factorial MANOVA. Using Wilks's criterion, I found no significant effect for a history of PA, $F(5,499)=1.21, p=.30$; a history of $E A, F(5,499)=.65, p=.66$; or a history of $S A, F(5,499)=1.33, p=.89$, and none of the interactions was significant.

To examine the relationship between the combined abuse severity scores and general childhood memory, the five childhood memory items were weighted equally and combined to form a single measure of quality of general childhood memory. First, I converted the responses to these five items to $z$ scores, and then I summed the responses to the first four items (higher scores indicate better memory) and subtracted the fifth item from that subtotal (younger ages in one's first memory indicate better childhood memory). The correlation between this measure and the combined abuse severity scores was nonsignificant, $r(511)=-.04, p=.25$.

The study participants were also asked if they had ever recovered memories of their childhoods in general. Nearly two thirds of the participants (63\%) indicated that they had recovered at least one memory of their childhoods (see Appendix). There was no significant difference between men and women in the number of recovered childhood memories reported, $t(529)=1.17, p=.24$. A $2 \times 2 \times 2$ factorial analysis of variance (ANOVA) was used to determine if those with a history of the different forms of child abuse had recovered different amounts of childhood memories than those without such histories. None of the $F$ values for the main effects of a history of PA, EA, or SA was significant, $F s(3,527)=.38, p=.54 ; 3.15, p=.08$; and .19, $p=.67$, respectively, and none of the interactions was significant. The combined abuse severity scores were also unrelated to the number of recovered childhood memories reported, $r(535)=.07, p=.08$.

\section{Memory for Childhood Abuse}

Participants who reported experiencing PA, EA, or SA were asked about the clarity and accuracy of their abuse memories, and there was substantial variance in the reported clarity of the abuse memories for all three abuse groups (see Table 3). Of those who indicated experiencing just one of the three forms of child abuse, comparisons between the three abuse groups in clarity of abuse memories revealed no significant differences in reported clarity of abuse memories, $F(2,58)=1.83, p=.17$, or in beliefs regarding the accuracy of abuse memories, $F(2,49)=.66, p=.52$. Responses to the clarity and accuracy of abuse memory items were highly correlated (.72 for PA, .74 for EA, and .69 for SA) and were combined to form a single measure of participants' perceptions of the accuracy of their abuse memories. Female participants reported significantly more accurate memories for their abuse experiences than the male participants: (a) PA female $M=3.9, S D=1.1$; male $M=2.5$, $S D=1.5 ; t(58)=4.03, p<.001$; (b) EA female $M=4.0, S D=0.9$; male $M=2.7, S D=1.3 ; t(85)=5.13, p<.001$; and (c) SA female $M=4.1, S D=1.0$; male $M=2.3, S D=1.3 ; t(64)=5.58, p<.001$. There was a significant positive correlation between the combined abuse severity scores and PA memory accuracy, $r(62)=.39, p=.002$, and between the combined abuse severity scores and EA memory accuracy, $r(88)=.27, p=.01$. The correlation 
between the combined abuse severity measure and SA memory accuracy, however, was not significant, $r(66)=$ $.07, p=.60$.

Table 3. Memories of Abuse ( $n$ and Percentage Reporting Each Response) for the Physical Abuse (PA), Emotional Abuse (EA), and Sexual Abuse (SA) Groups

\begin{tabular}{|c|c|c|c|c|c|c|}
\hline & Group & & & & & \\
\hline & PA & & EA & & SA & \\
\hline Item & $\mathbf{n}$ & $\%$ & $\mathbf{n}$ & $\%$ & $\mathbf{n}$ & $\%$ \\
\hline \multicolumn{7}{|l|}{$\begin{array}{l}\text { How clear are your memories for the physical/emotional/sexual } \\
\text { abuse? }\end{array}$} \\
\hline 1. I have only a vague sense that something happened. & 26 & 35 & 13 & 14 & 12 & 18 \\
\hline 2. [No anchor statement] & 5 & 7 & 7 & 8 & 7 & 11 \\
\hline 3. Some of the memories are blurry, but I think they are accurate. & 12 & 16 & 27 & 30 & 11 & 17 \\
\hline 4. [No anchor statement] & 10 & 13 & 13 & 14 & 7 & 11 \\
\hline 5. I can remember exactly what happened and how it felt. & 22 & 29 & 31 & 34 & 29 & 44 \\
\hline \multicolumn{7}{|l|}{$\begin{array}{l}\text { How accurate do you think your physical/emotional/sexual abuse } \\
\text { memories are? }\end{array}$} \\
\hline 1. Could be completely false & 10 & 16 & 10 & 11 & 8 & 12 \\
\hline 2. Maybe false & 4 & 6 & 11 & 12 & 3 & 4 \\
\hline 3. Probably some significant errors & 5 & 8 & 10 & 11 & 4 & 6 \\
\hline 4. Mostly accurate & 27 & 42 & 37 & 42 & 31 & 45 \\
\hline 5. Perfectly accurate, exactly as I remember it happening & 18 & 28 & 21 & 24 & 23 & 33 \\
\hline \multicolumn{7}{|l|}{$\begin{array}{l}\text { Was there ever a time when you had no memories of your } \\
\text { physical/emotional/sexual abuse, and then later the memories } \\
\text { came back to you? }\end{array}$} \\
\hline 1. Yes & 13 & 21 & 15 & 18 & 13 & 18 \\
\hline 2. No & 48 & 79 & 70 & 82 & 59 & 82 \\
\hline $\begin{array}{l}\text { If "Yes," how old were you the first time you remembered the } \\
\text { abuse? }\end{array}$ & $14.9^{\mathrm{a}}$ & $7.8^{\mathrm{b}}$ & $12.6^{\mathrm{a}}$ & $7.3^{b}$ & $14.9^{\mathrm{a}}$ & $8.4^{b}$ \\
\hline \multicolumn{7}{|l|}{ Which of the following is true of you? } \\
\hline $\begin{array}{l}\text { 1. I would not have been able to remember the abuse even if } \\
\text { someone had told me about it because I simply did not have } \\
\text { any memories of it at that time. }\end{array}$ & 3 & 25 & 5 & 42 & 0 & 0 \\
\hline $\begin{array}{l}\text { 2. I could have remembered it during that time if! had wanted to } \\
\text { think about it or someone had reminded me ofit- } 1 \text { was mainly } \\
\text { just avoiding the memories at that time. }\end{array}$ & 4 & 33 & 5 & 42 & 10 & 77 \\
\hline 3. Other (please write in): & 5 & $42^{c}$ & 2 & $17^{d}$ & 3 & $23^{c}$ \\
\hline \multicolumn{7}{|l|}{ Why do you think you could not remember the abuse? } \\
\hline 1. I was intentionally trying not to think about the memories. & 1 & 8 & 3 & 23 & 0 & 0 \\
\hline $\begin{array}{l}\text { 2. Apparently I had repressed it-I unconsciously blocked out the } \\
\text { memories because it would have been too painful to } \\
\text { remember it. }\end{array}$ & 7 & 54 & 5 & 31 & 7 & 54 \\
\hline $\begin{array}{l}\text { 3. The memories just came back to me-apparently I had just } \\
\text { forgotten about it. }\end{array}$ & 1 & 8 & 1 & 8 & 1 & 8 \\
\hline $\begin{array}{l}\text { 4. I could always remember what happened, but I did not think of } \\
\text { it as abuse until I was older. }\end{array}$ & 1 & 8 & 3 & 23 & 4 & 31 \\
\hline $\begin{array}{l}\text { 5. I was using a lot of alcohol and/or drugs or engaged in other } \\
\text { compulsive behavior to help me avoid thinking about it. }\end{array}$ & 1 & 8 & 1 & 8 & 1 & 8 \\
\hline
\end{tabular}


6. Other (please write in):

2

\begin{tabular}{|l|l|}
\hline $15^{f}$ & 1
\end{tabular}

$8^{\mathrm{g}}$

0

0

Note. These questions were repeated three times in regard to PA, EA, and SA.

${ }^{a}$ These values represent the mean age (in years).

${ }^{b}$ These values represent the standard deviation (in years).

' Written in responses: "Some abuse I didn't forget, some I was reminded of and some I still don't remember,"

"A certain smell or object would trigger it," "Just didn't remember till later-blackout," "I was the only one who knew in my family-I just remembered one day," and "My mind blocked it out and it was brought back by my father years later."

${ }^{\mathrm{d}}$ Written in responses: "Remember some and some was blocked," and "Father told me."

e Written in responses: "I was the only one who knew in my family-I just remembered one day," "I remembered it when I saw him again," and "Don't know how I remembered."

${ }^{f}$ Written in responses: "Talked to sister and ex-stepmom about some of the things that happened," and "An eighth grade teacher began asking questions about another problem in my home life."

${ }^{g}$ Written in response: "Talked to sister and ex-stepmom about things that happened."

When those participants who reported a history of PA, EA, or SA were asked if there was ever a time when they had no memories of the abuse but the memories later returned to them, very similar proportions of all three groups (18\% to $21 \%$ ) reported that they had recovered abuse memories. There were no significant gender differences in the proportion of women and men who reported recovering PA, EA, and SA memories. For those who reported experiencing just one type of child abuse, there was also no significant difference in the proportion who reported recovering abuse memories between the PA, EA, and SA groups, $\chi^{2}(2, N=52)=.57, p=$ .75. For all of those who had experienced child abuse, there was a nearly significant association between the combined abuse severity scores and reporting recovered PA memories, $r(67)=.30, p=.013$, but not EA memories, $r(87)=-.09, p=.41$, or SA memories, $r(72)=-.14, p=.24$. There was also no significant correlation between age when the SA occurred and recovering SA memories, $r(43)=.24, p=.11$, for age when the abuse began; $r(42)=.20, p=.21$, for age when the abuse ended.

Those who reported recovering abuse memories were asked if they believed they had conscious access to the memories during the period when the memories were missing, or if they would not have been able to recall the abuse because they lacked conscious access to the memories (see Table 3 ). A substantial proportion of all three groups (33\% to $77 \%$ ) indicated that they could have remembered the abuse if they had wanted to think about it or had been reminded of it, and a minority of the respondents ( $0 \%$ to $42 \%$ ) reported that they would not have been able to recall the abuse because they had no memories of the abuse for a period (see also the "other" responses in Table 3 ). The sizes of the subgroups indicating these responses were insufficient, however, for conducting reliable statistical analyses on the association between these responses and other participant characteristics.

When those who reported a lack of continuous recall for their abuse were asked about the process that they thought accounted for the missing period of memory, the largest group for all three abuse types indicated that they had repressed the abuse (i.e., "unconsciously blocked out the memories"). Nearly one half of those indicating that they had repressed the abuse (43\% of the PA group, $25 \%$ of the EA group, $57 \%$ of the SA group), however, had previously indicated that they would have been able to recall the abuse if they had not been "mainly just avoiding the memories." The next largest group for all three abuse types indicated that they could always recall the abuse but had not interpreted the experiences as abuse until they were older (see Table 3 for other responses). Again, the numbers of participants in each cell was insufficient for conducting reliable statistical analyses on these responses.

These results suggest that several of those who indicated that they lacked continuous recall for their child abuse apparently did not lack conscious access to the abuse memories, but, rather, had consciously attempted to avoid the memories or had reinterpreted their experiences as abusive only later in their lives. Overall, there were 20 
participants who indicated that they had recovered at least one type of abuse memory (i.e., $15 \%$ of the total abuse sample who answered these questions). Of these individuals, 11 (8\%) endorsed or wrote in responses to these two items that suggested a relatively clear lack of conscious access to their abuse memories: Two indicated that "The memories just came back to me-apparently I had just forgotten about it," two indicated that "Apparently I had repressed it," and an additional seven wrote in responses suggesting a lack of conscious access to the memories (i.e., "Some abuse I didn't forget, some I was reminded of, and some I still don't remember [after talking with her sister and ex-stepmother about]" things that happened]." "An eighth grade teacher began asking questions about another problem in my home life." "A certain smell or object would trigger it." "I was the only one who knew in my family-I just remembered one day." "My mind blocked it out and it was brought back by my father years later." "I remembered it when I saw him again." and "Don't know how I remembered."). Seven of these 11 individuals indicated recovering PA memories, four indicated recovering EA memories, and three indicated recovering SA memories (three participants indicated recovering memories of two types of abuse). Some of these 11 individuals had combined abuse severity scores that were quite high, but two also had scores below the mean for the entire study sample $(M=3.9, S D=4.6$, range $=-.60$ to 15.0$)$.

\section{Discussion}

Before discussing the results of this study, it is useful to emphasize the primary limitation of the data presented, namely, the unknown reliability of the participants' self-reported perceptions and memories of their child abuse. Although the veridicality of these memories was not the focus of this study, it must be pointed out that the findings are based on the reports of some individuals who indicated that they do not fully trust the accuracy of some of their childhood memories. Most memory experts have concluded that autobiographical memory is relatively accurate (Baddeley, 1990; Barclay, 1986; Brewer, 1994; Brewin, Andrews, \& Gotlib, 1993; $\underline{\text { Heuer \& }}$ Reisberg, 1992; Neisser, 1994; Ross \& Conway, 1986); consequently, the memories reported by the participants in this study would be expected to carry some semblance to actual events, but they certainly would not be expected to be perfectly accurate. Therefore, though the memories reported are of imperfect reliability, they are nevertheless likely to help clarify the understanding of child abuse and memory. The data for this study were also obtained from college student participants, and the generalizability of the current findings to clinical populations is unknown. However, many college students with child abuse histories eventually become mental health clients; consequently, the experiences of the study sample are likely to be generalizable to at least part of the clinical population.

This study addressed several questions that have not been examined in previous research, but the findings, if replicated, have considerable implications for the understanding of the relationship between child abuse and memory. The study participants reported a remarkably wide range in the quality of their general childhood memory, including wide variation in their age in their earliest memories. There was also great variance in the number of recovered memories reported by the study participants. In fact, according to the self-reports of these participants, it appears to be normative to recover childhood memories ( $63 \%$ of the sample reported recovering at least one childhood memory). No significant relationships were found, however, between experiencing child abuse and either the quality of general childhood memory or the number of recovered childhood memories. Of course, if there is a significant number of participants who eventually recover veridical memories of child abuse and also have poor childhood memory generally, these findings would change. If that possibility does not actually materialize in this sample, however, the study findings are in direct contrast to hypotheses suggesting that a history of child abuse is associated with poor (or enhanced) memory for early childhood.

The proportions of the PA and EA subsamples in this study who reported recovering abuse memories (21\% and $18 \%$, respectively) were very similar to the proportion of the SA subsample who reported recovering abuse memories (18\%). These proportions are also very similar to the proportion found by Loftus, Polonsky, and Fullilove (1994) -19\% - and they are close to the proportion who reported no history of SA-12\% -in Williams's (1994) study. The mean age of when these memories were recovered was during early to middle adolescence, 
but the variance was large. Therefore, it is quite possible that additional participants will recover abuse memories with time. The mean age of when abuse memories were recovered was not reported in the other studies on this subject, so comparisons with other samples regarding this issue cannot be made at this time.

It appears, however, that several of the study participants did not necessarily lack conscious access to their abuse memories before these memories were reported as having been recovered. In fact, nearly one half of those who indicated that they thought they had unconsciously repressed their memories also indicated that they "could have remembered it ... if I had wanted to think about it or someone had reminded me of it-I was mainly just avoiding the memories at that time." It is not possible to know how the participants interpreted the various questionnaire items, because their responses were not clarified in follow-up interviews. Perhaps some of those who chose this response actually meant that they were unconsciously avoiding their abuse memories. As noted earlier, however, scientists and practitioners since Freud have offered a variety of views regarding the nature of repression, and the present findings raise the possibility that laypersons also hold dissimilar views of repression. The responses of approximately one half of the participants who reported recovering abuse memories (11 of the 20), on the other hand, suggest fairly clearly that they did lack conscious access to their abuse memories for a period. It is unfortunate that these participants' responses could not also be differentiated in terms of unconscious repression versus simple forgetting, both of which are subconscious processes but which putatively involve quite different psychological mechanisms. Nevertheless, the responses of these participants, which represent $8 \%$ of the total abuse sample, suggest relatively clearly that abuse memories were recovered after a period when the memories had been outside of awareness. (All of the participants' responses to the various items are listed so that readers can arrive at their own interpretations of these results.)

The primary purpose for including both women and men in this study was to collect evidence for addressing the hypothesis that the recovery of false SA memories primarily affects women. In contrast to that hypothesis, this study found only one significant gender difference in childhood memory. I found no gender differences in (a) general quality of childhood memory, (b) number of general recovered memories of childhood, or (c) number of recovered abuse memories. The only significant gender difference found was in beliefs about the accuracy of childhood abuse memories. These findings suggest that assumptions regarding the role that gender may play in the recovery of child abuse memories are unwarranted, and that care should be taken not to allow an unjustified gender bias to enter the professional literature or practice regarding this issue, at least until further research can be conducted.

Autobiographical memory is obviously very difficult to verify, and it is impossible to verify the accuracy of many childhood memories (e.g., even many reports of current child abuse cannot be verified by child protective service workers; Everson \& Boat, 1989; Jones \& McGraw, 1987). Innovative longitudinal research methodologies can help establish the accuracy of childhood recall (e.g., see Williams, 1994), but these methodologies also have limitations (e.g., see Loftus, Garry, \& Feldman, 1994). Given that many memory experts believe that autobiographical memory is relatively accurate, individuals' self-reported recall of their childhoods, such as that investigated in the current study, should also help psychologists understand various aspects of childhood memory. The accuracy of the memories reported in this study remains unknown, of course, and if significant numbers of the participants were to eventually recover veridical abuse memories, the study findings would change. Nevertheless, the participants' reports of their experiences to date have several direct implications for clinical practice. These reports suggest that there is a large amount of variance in individuals' childhood memories, and that the experience of different forms of child abuse, either singly or in combination, are not related to the general quality of childhood memory or the recovery of childhood memories. Approximately one in seven of the study participants reporting a history of child abuse reported that there had been a period when they had no memories of their abuse, but it appears that the participants were referring to a variety of processes when they reported that they recovered childhood abuse memories, some of which do not suggest a lack of access to the abuse memories. This finding would suggest that practitioners should attempt to clarify what clients mean when they report recovering abuse memories. Furthermore, practitioners should recognize 
that recovering childhood memories may be normative and unrelated to experiencing child abuse. The large amount of variance in abuse memory accuracy reported by the participants suggests another variable that practitioners should take into consideration when assessing the nature of clients' abuse memories.

Recovered SA memories, not PA or EA memories, have received the preponderance of attention in the controversy regarding repressed and recovered child abuse memories, but the findings of this study suggest that the experience of SA may have no unique effects on memory as compared with other types of abuse. Indeed, no unique effects on childhood memory were found for any form of abuse. There may be individual differences that would explain significant amounts of the variance in childhood memory that was found in this study, but the findings suggest that a history of child abuse is not one of these differences. Given the importance of these issues to both psychological theory and practice, these findings are in great need of replication and extension. Even before that can be done, however, the findings suggest that child abuse memories should be processed and interpreted cautiously when they are encountered in professional practice. In addition, the finding that just over one quarter of the nonclinical sample in this study reported experiencing at least one of the three types of child abuse reemphasizes the tragedy of child maltreatment in our society, a problem that also deserves more research attention.

\section{Footnotes}

1 Participants' ratings of the severity of their PA and EA (on a scale of 1 to 5 , with no abuse scored 0 ) along with their number of reported SA incidents were converted to $z$ scores, because one of these three measures used a different metric than the other two. The $z$ scores were then summed. The resulting combined abuse severity scores ranged from -0.93 to $17.0(M=0.0, S D=2.3)$. In order to further assess level of severity of SA, participants were also asked how many times physical force was used by their SA perpetrators. The responses to these items correlated .82 with the number of SA incidents reported, but $20 \%$ of those who indicated a history of SA skipped these items. In order to avoid the exclusion of an inordinate number of participants from the analyses because of missing responses, the number of SA incidents was used as the measure of SA severity, because it assessed the incidence of SA while also being a reliable estimate of the frequency of violent SA perpetration.

\section{References}

American Medical Association Council on Scientific Affairs. (1994). Memories of childhood abuse (SA Report 5-A94). Chicago: American Medical Association.

American Psychiatric Association. (1980). Diagnostic and statistical manual of mental disorders (3rd ed.). Washington, DC: Author.

American Psychiatric Association. (1987). Diagnostic and statistical manual of mental disorders (3rd ed., rev.). Washington, DC: Author.

American Psychiatric Association. (1994). Diagnostic and statistical manual of mental disorders (4th ed.). Washington, DC: Author.

American Psychological Association. (1994December). Interim report issued on memories of abuse. APA Monitor. pp. 8-9.

Baddeley, A. D. (1990). Human memory: Theory and practice. Hillsdale, NJ: Erlbaum.

Bass, E., \& Davis, L. (1988). The courage to heal. New York: Harper \& Row.

Barclay, C. R. (1986). Schematization of autobiographical memory. In D. C.Rubin (Ed.), Autobiographical memory (pp. 82-99). New York: Cambridge University Press.

Blume, E. S. (1990). Secret survivors. New York: Wiley.

Brewer, W. F. (1994). Autobiographical memory and survey research. In N.Schwarz \& S.Sudman (Eds.), Autobiographical memory and the validity of retrospective reports (pp. 11-20). New York: SpringerVerlag.

Brewin, C. R., Andrews, B., \& Gotlib, I. H. (1993). Psychopathology and early experience: A reappraisal of retrospective reports. Psychological Bulletin, 113, 82-98. 
Briere, J. (1988). The long-term clinical correlates of childhood sexual victimization. Annals of the New York Academy of Sciences, 528, 327-334.

Briere, J. (1992). Methodological issues in the study of sexual abuse effects. Journal of Consulting and Clinical Psychology, 60, 196-203.

Briere, J., \& Conte, J. (1993). Self-reported amnesia for abuse in adults molested as children. Journal of Traumatic Stress, 6, 21-31.

Browne, A., \& Finkelhor, D. (1986). Impact of child sexual abuse: A review of the research. Psychological Bulletin, 99, 66-77.

Ceci, S. J., \& Bruck, M. (1995). Jeopardy in the courtroom: A scientific analysis of children's testimony. Washington, DC: American Psychological Association.

Courtois, C. A. (1988). Healing the incest wound: Adult survivors in therapy. New York: Norton.

Ellenson, G. S. (1985). Detecting a history of incest: A predictive syndrome. Social Casework: The Journal of Contemporary Social Work, 66, 525-532.

Erdelyi, M. H. (1990). Repression, reconstruction, and defense: History and integration of the psychoanalytic and experimental frameworks. In J. L.Singer (Ed.), Repression and dissociation: Implications for personality theory, psychopathology, and health (pp. 1-32). Chicago: University of Chicago Press.

Everson, M. D., \& Boat, B. W. (1989). False allegations of sexual abuse by children and adolescents. Journal of the American Academy of Child and Adolescent Psychiatry, 28, 230-235.

Finkelhor, D., Hotaling, G., Lewis, I. A., \& Smith, C. (1990). Sexual abuse in a national survey of adult men and women: Prevalence, characteristics, and risk factors. Child Abuse and Neglect, 14, 19-28.

Frederickson, R. (1992). Repressed memories: A journey to recovery from sexual abuse. New York: Simon \& Schuster.

Ganaway, G. K. (1989). Historical versus narrative truth: Clarifying the role of exogenous trauma in the etiology of MPD and its variants. Dissociation, 2, 201-205.

Ganaway, G. K. (1991, August). Alternative hypotheses regarding satanic ritual abuse memories. Paper presented at the 99th Annual Convention of the American Psychological Association, San Francisco, CA.

Ganaway, G. K. (1995). Hypnosis, childhood trauma, and dissociative identity disorder: Toward an integrative theory. International Journal of Clinical and Experimental Hypnosis, 43, 127-144.

Gardner, R. A. (1992). Belated realization of child sex abuse by an adult. Issues in Child Abuse Accusations, 4, 177-195.

Henderson, J. L., \& Moore, M. M. (1944). The psychoneuroses of war. New England Journal of Medicine, 230, $272-278$.

Herman, J. L. (1992). Trauma and recovery. New York: Basic Books.

Herman, J. L., \& Schatzow, E. (1987). Recovery and verification of memories of childhood sexual trauma. Psychoanalytic Psychology, 4, 1-14.

Holmes, D. S. (1974). Investigations of repression: Differential recall of material experimentally or naturally associated with ego threat. Psychological Bulletin, 81, 632-653.

Holmes, D. S. (1990). The evidence for repression: An examination of sixty years of research. In J. L.Singer (Ed.), Repression and dissociation: Implications for personality theory, psychopathology, and health (pp. 85102). Chicago: University of Chicago Press.

Heuer, F., \& Reisberg, D. (1992). Emotion, arousal, and memory for detail. In S.Christianson (Ed.), Handbook of emotion and memory: Research and theory (pp. 151-180). Hillsdale, NJ: Erlbaum.

Janet, P. (1889). Psychological automatisms. Paris: Alcan.

Jones, D. P. H., \& McGraw, J. M. (1987). Reliable and fictitious accounts of sexual abuse of children. Journal of Interpersonal Violence, 2, 27-45.

Kempe, C. H., Silverman, F. M., Steele, B. F., Droegemueller, W., \& Silver, H. K. (1962). The battered-child syndrome. Journal of the American Medical Association, 181, 145-155.

Lanning, K. V. (1992). Investigator's guide to allegations of "ritual" child abuse. Quantico, VA: U.S. Department of Justice, National Center for the Analysis of Violent Crime. 
Lindsay, D. S., \& Read, J. D. (1994). Psychotherapy and memories of childhood sexual abuse: A cognitive perspective. Applied Cognitive Psychology, 8, 281-338.

Loftus, E. F. (1993). The reality of repressed memories. American Psychologist, 48, 518-537.

Loftus, E. F., \& Burns, T. E. (1982). Mental shock can produce retrograde amnesia. Memory and Cognition, 10, 318-323.

Loftus, E. F., Garry, M., \& Feldman, J. (1994). Forgetting sexual trauma: What does it mean when $38 \%$ forget?Journal of Consulting and Clinical Psychology, 62, 1177-1181.

Loftus, E. F., Polonsky, S., \& Fullilove, M. T. (1994). Memories of childhood sexual abuse: Remembering and repressing. Psychology of Women Quarterly, 18, 67-84.

Maltz, W. (1990, December). Adult survivors of incest: How to help them overcome the trauma. Medical Aspects of Human Sexuality. pp. 42-47.

Melchert, T. P., \& Sayger, T. V. (1996). The development of an instrument for measuring family-of-origin characteristics. Educational and Psychological Measurement. in press.

Neisser, U. (1994). Self-narratives: True and false. In U.Neisser \& R.Fivush (Eds.), The remembering self: Construction and accuracy in the self-narrative (pp. 1-18). New York: Cambridge University Press.

Ofshe, R. J., \& Singer, M. T. (1993). Recovered memory therapies and robust repression: A collective error. Unpublished manuscript, University of California, Berkeley.

Ofshe, R. J., \& Watters, E. (1993). Making monsters. Society, 30, 4-16.

Pendergrast, M. (1995). Victims of memory: Incest accusation and shattered lives. Hinesburg, VT: Upper Access.

Pezdek, K. (1994). The illusion of illusory memory. Applied Cognitive Psychology, 8, 339-350.

Pope, H. G., \& Hudson, J. I. (1995). Can memories of childhood sexual abuse be repressed?Psychological Medicine, 25, 121-126.

Ross, M., \& Conway, M. (1986). Remembering one's own past: The construction of personal histories. In R. M.Sorrentino \& E. T.Higgins (Eds.), Handbook of motivation and cognition: Foundations of social behavior (pp. 122-144). New York: Wiley.

Schacter, D. L. (1995). Memory distortion: History and current status. In D. L.Schacter, J. T.Coyle, G. D.Fischbach, M. M.Mesulam, \& L. E.Sullivan (Eds.), Memory distortion (pp. 1-46). Cambridge, MA: Harvard University Press.

Singer, J. L. (1990). Preface: A fresh look at repression, dissociation, and the defenses as mechanisms and as personality styles. In J. L.Singer (Ed.), Repression and dissociation: Implications for personality theory, psychopathology, and health (pp. xi-xxiii). Chicago: University of Chicago Press.

Spiegel, H. (1980). Hypnosis and evidence: Help or hindrance?Annals of the New York Academy of Sciences, 347, 73-85.

Starr, R. H.Jr., Dubowitz, H., \& Bush, B. A. (1990). The epidemiology of child maltreatment. In R. T.Ammerman \& M.Hersen (Eds.), Children at risk: An evaluation of factors contributing to child abuse and neglect (pp. 23-53). New York: Plenum.

Terr, L. C. (1991). Childhood traumas: An outline and overview. American Journal of Psychiatry, 148, 10-20.

Tobias, B. A., Kihlstrom, J. F., \& Schacter, D. L. (1992). Emotion and implicit memory. In S.Christianson (Ed.), Handbook of emotion and memory: Research and theoryHillsdale, NJ: Erlbaum.

van der Kolk, B. A., \& Kadish, W. (1987). Amnesia, dissociation, and the return of the repressed. In B. A.van der Kolk (Ed.), Psychological trauma (pp. 173-190). Washington, DC: American Psychiatric Press.

Wakefield, H., \& Underwager, R. (1992). Recovered memories of alleged sexual abuse: Lawsuits against parents. Behavioral Sciences and the Law, 10, 483-507.

Williams, L. M. (1994). Recall of childhood trauma: A prospective study of women' memories of child sexual abuse. Journal of Consulting and Clinical Psychology, 62, 1167-1176.

APPENDIX

APPENDIX A: Responses to General Childhood Memory Items 


\begin{tabular}{|c|c|c|c|c|c|c|c|c|c|c|c|c|c|c|c|}
\hline $\begin{array}{l}\text { How old were you in } \\
\text { your earliest memory } \\
\text { that you have? }\end{array}$ & & & & & & & & & & & & & & & \\
\hline Age & 1 & 2 & 3 & 4 & 5 & 6 & 7 & 8 & 9 & 10 & 11 & 14 & 15 & 16 & 17 \\
\hline$\%$ & 5.1 & 29.6 & 17.7 & 22.0 & 15.8 & 2.9 & 1.4 & 1.8 & 0.8 & 1.6 & 0.6 & 0.2 & 02. & 0.2 & 0.2 \\
\hline
\end{tabular}

\begin{tabular}{|c|c|c|c|c|c|}
\hline $\begin{array}{l}\text { What is your } \\
\text { memory like for } \\
\text { your childhood at: }\end{array}$ & $\begin{array}{l}\text { No memories } \\
\text { at all }\end{array}$ & $\begin{array}{l}\text { I can } \\
\text { remember } 1 \\
\text { or } 2 \text { things }\end{array}$ & $\begin{array}{l}\text { I can } \\
\text { remember } \\
\text { several things }\end{array}$ & $\begin{array}{l}\text { I can remember } \\
\text { most of my } \\
{\left[2^{\text {nd }}-10^{\text {th }}\right] \text { year }}\end{array}$ & $\begin{array}{l}\text { Very clear- } \\
\text { there are no } \\
\text { periods that I } \\
\text { cannot } \\
\text { remember }\end{array}$ \\
\hline Age 10? (\%) & 1.8 & 12.0 & 50.1 & 26.8 & 9.3 \\
\hline Age 7 ? $(\%)^{a}$ & 2.7 & 30.4 & 47.7 & 13.8 & 5.3 \\
\hline Age 5? $(\%)^{a}$ & 9.8 & 45.7 & 33.5 & 8.0 & 2.9 \\
\hline Age 2? $(\%)^{a}$ & 52.6 & 37.2 & 8.4 & 1.3 & 0.5 \\
\hline $\begin{array}{l}\text { Have you ever } \\
\text { remembered things } \\
\text { about your } \\
\text { childhood that you } \\
\text { had not } \\
\text { remembered } \\
\text { before? }\end{array}$ & $\begin{array}{l}\text { Never } \\
\text { remembered } \\
\text { new things }\end{array}$ & $\begin{array}{l}\text { Remembered } \\
1 \text { new thing }\end{array}$ & $\begin{array}{l}\text { Remembered } \\
2 \text { or } 3 \text { new } \\
\text { things }\end{array}$ & $\begin{array}{l}\text { Remembered } \\
\text { several new } \\
\text { things }\end{array}$ & $\begin{array}{l}\text { Remembered } \\
\text { many new things }\end{array}$ \\
\hline$\%$ & 36.8 & 16.38 & 34.4 & 8.6 & 3.7 \\
\hline
\end{tabular}

${ }^{a}$ Differences between ages 10 and 7, 7 and 5, and 5 and 2 all significant, $p<.001$ 